\title{
INITIAL TESTS ON SELECTED SEROLOGICAL REACTIONS IN RABBITS BURNT WITH NAPALM AND SUBJECTED TO HYPERBARIC OXYGENATION
}

\author{
Kazimierz Ulewicz ${ }^{1)}$, Przemysław Michniewski ${ }^{1)}$, Brunon Kierznikowicz ${ }^{1)}$, Bogdan Łokucijewski ${ }^{1)}$, \\ Jan Stencel ${ }^{2)}$ \\ ${ }^{1)}$ Maritime Medicine Departament Military Medical University, Gdynia, Poland \\ ${ }^{2)}$ Pathology Departament 8 Naval Hospital, Gdańsk, Poland
}

\section{ABSTRACT}

Hyperbaric oxygenation therapy has found its application in the treatment of various types of burns. The presented work describes the use of this method in treating napalm burns in experimental animals. The researchers took particular interest in the immunological reactions occurring in animals, as well as the effect of the said therapy on the healing process.

Two groups of rabbits, previously anaesthetised with Evipan and immunised with $S$. typhi phage $F_{7}$ microorganisms, were burnt with the use of napalm. The tested group was subjected to a series of treatment sessions with $100 \%$ oxygen at the pressure of 2 atm, whereas the control group did not undergo such treatment. Six repeated tests on complement activity with $50 \%$ haemolysis method and heamagglutination reaction quantification with antigens $\mathrm{O}$ and $\mathrm{H}$ S.typhi phage $\mathrm{F}_{7}$ were carried out on all of the researched animals. Moreover, for the purpose of control of the healing process, a number of histopathological exams on the burn wounds were conducted in both groups of rabbits.

The research showed an increase in complement activity in all tested animals; however, in the tested group it occurred later. Histopathological tests confirmed a more advanced healing process in the group subjected to hyperbaric oxygenation.

Key words: Hyperbaric oxygenation therapy, complement activity reaction, haemagglutination reaction, burn wound histopathology.

ARTICLE INFO

PolHypRes 2015 Vol. 50 Issue 1 pp. 55 - 60

ISSN: $1734-7009$ elSSN: $2084-0535$

DOI: $10.1515 /$ phr-2015-0005

Pages: 6, figures: 0, tables: 2

page www of the periodical: www.phr.net.pl

Publisher

Polish Hyperbaric Medicine and Technology Society

\section{Original article}

Originally published in Journal of Naval Health Service 1973

Date of approval for print in PolHyp Res.: 2.03.2015r. 


\section{INTRODUCTION}

In recent years, hyperbaric oxygen has been attributed to an increasing number of applications in the treatment of various health conditions.

Although, according to recently established views, hyperbaric oxygenation is a treatment method of choice only with regard to carbon monoxide poisoning, gas gangrene or, partially, decompression sickness [7, 8], nonetheless utilisation of this method has also obtained encouraging results in treating other conditions, including some purulent infections, peripheral arterial disease and certain tumors, which become more sensitive to radiotherapy after hyperbaric oxygenation therapy, etc. $[7,8]$.

Moreover, apart from the above conditions, positive outcomes have been obtained in treating different types of burns $[13,7,5,8]$ including those resulting from an electric shock [12].

The lack of own observations related to this topic, and moreover the long-term studies conducted on the effect of hyperbaric oxygenation of systemic immunological reactions $[1,9,10,11]$ persuaded the authors to carry out initial indicative research on the behaviour of certain serological reagents in experimental animals with induced burns, subjected to hyperbaric oxygenation therapy.

\section{MATERIAL AND METHOD}

The study was conducted on a series of 7 rabbits with an average weight of $2.5 \mathrm{~kg}$, male and female, previously immunised with $\mathrm{S}$. typhi phage $\mathrm{F}_{7}$ microorganisms according to the scheme applied in a former study $[10,11] .2$ weeks after the vaccination, the animals were depilated on the back and burnt with napalm within an area of $4.5 \times 5 \mathrm{~cm}^{2}$, with the flame maintained for 45 seconds. In the course of the procedure the rabbits were anesthetized with Evipan administered intravenously in the dose of $40 \mathrm{mg} / \mathrm{kg}$ bw.

The animals were divided into two groups, of which the first consisted of four rabbits treated with 100\% oxygen at a pressure of 2 ata, in two rounds of 60 minutes with 6-hour intervals.

The treatment was repeated five times, preserving the same treatment regime. The second group consisting of three animals constituted the control group. In all of the tested animals, measurement of complement activity using the $50 \%$ hemolysis method was performed, as per the previously conducted tests [10].

The identification of the haemagglutination reaction to the antigens $\mathrm{O}$ and $\mathrm{H}$ as used in the immunisation [11], immunoelectrophoresis of IgG micro immunoglobulins according to Scheidegger [10], and the antistaphylolizin, were estimated utilising the BEHRINGWERKE reagents.

The said tests were performed before burning as well as after the lapse of 12, 24 hours and following 2, 3, 4 and 6 days from the thermal injury. In each case the clinical condition of the animals was continuously monitored.

For the purpose of control of the pathological process occurring in the burns, additionally 6 rabbits were burnt in an identical manner and submitted to histopathological testing.
Material samples were taken from the burn wounds, fixed in $10 \%$ formalin, immersed in formalin, cut and stained with haematoxylin with eosin and evaluated with Masson's method with regard to collagen and Verhoeff's method with regard to elastic fibres. Histopathological examination was performed immediately following the burn, and then after 24 hours, 8 days and 40 days from the thermal injury.

Moreover, it needs to be mentioned that the presented material included an animal that had previously been subjected to hyperbaric oxygenation after being burnt with napalm.

\section{RESULTS}

The obtained quantification results for the activity of the complement using the $50 \%$ hemolysis method are presented in Table I, whereas the comparison of quantification results obtained in the haemagglutination test for antigen $\mathrm{O}$ and $\mathrm{H}$. typhi $\mathrm{F}_{7}$ in Table II. 
Comparison of results related to complement activity.

\begin{tabular}{|c|c|c|c|c|c|c|c|c|c|c|c|c|c|c|}
\hline \multirow{3}{*}{$\begin{aligned} \text { Animal } & \\
& \\
& 1\end{aligned}$} & \multicolumn{10}{|c|}{ Burnt group - treated with hyperbaric oxygenation } & & & & \\
\hline & \multicolumn{2}{|c|}{$\begin{array}{l}\text { Quantification } \\
\text { done prior to } \\
\text { burning }\end{array}$} & \multicolumn{2}{|c|}{$\begin{array}{l}12 \text { hours } \\
\text { after } \\
\text { burning }\end{array}$} & \multicolumn{2}{|c|}{$\begin{array}{l}24 \text { hours } \\
\text { after } \\
\text { burning }\end{array}$} & \multicolumn{2}{|c|}{$\begin{array}{l}2 \text { days after } \\
\text { burning }\end{array}$} & \multicolumn{2}{|c|}{$\begin{array}{l}3 \text { days after } \\
\text { burning }\end{array}$} & \multicolumn{2}{|c|}{$\begin{array}{l}4 \text { days after } \\
\text { burning }\end{array}$} & \multicolumn{2}{|c|}{$\begin{array}{l}6 \text { days after } \\
\text { burning }\end{array}$} \\
\hline & & 2 & & 3 & & 4 & & 5 & & 6 & & 7 & & 8 \\
\hline \multirow[t]{2}{*}{ Rabbit no. 1} & & $17 \mathrm{u}$. & & 12 & & 13 & & 13 & & 15 & & 15 & & 17 \\
\hline & & & $.9 \mathrm{u}$. & & $.5 \mathrm{u}$ & & $.5 \mathrm{u}$. & & $.5 \mathrm{u}$. & & $.2 \mathrm{u}$. & & $.8 \mathrm{u}$. & \\
\hline \multirow[t]{2}{*}{ Rabbit no. 4} & & 18.2 & & 16 & & 15 & & 15 & & 19 & & 18 & & 20 \\
\hline & u. & & $.6 \mathrm{u}$. & & $.2 \mathrm{u}$ & & $.2 \mathrm{u}$. & & $.1 \mathrm{u}$. & & $.8 \mathrm{u}$. & & $.5 \mathrm{u}$. & \\
\hline \multirow[t]{2}{*}{ Rabbit no. 5} & & 14.2 & & 12 & & 12 & & 12 & & 17 & & 15 & & 15 \\
\hline & u. & & $.9 \mathrm{u}$. & & $.6 \mathrm{u}$ & & $.6 \mathrm{u}$. & & $.8 \mathrm{u}$. & & $.9 \mathrm{u}$. & & $.5 \mathrm{u}$. & \\
\hline \multirow[t]{5}{*}{ Rabbit no. 6} & & 13.5 & & 13 & & 13 & & 13 & & 17 & & 16 & & 17 \\
\hline & u. & & $.5 \mathrm{u}$. & & $.0 \mathrm{u}$ & & $.0 \mathrm{u}$. & & $.4 \mathrm{u}$. & & $.3 \mathrm{u}$. & & $.4 \mathrm{u}$. & \\
\hline & & 15.7 & & 13 & & 13 & & 13 & & 17 & & 16 & & 17 \\
\hline & u. & & $.9 \mathrm{u}$. & & $.5 \mathrm{u}$ & & $.5 \mathrm{u}$. & & $.4 \mathrm{u}$. & & $.6 \mathrm{u}$. & & $.8 \mathrm{u}$. & \\
\hline & & Contr & group & - burn & & & & & & & & & & \\
\hline \multirow[t]{2}{*}{ Rabbit no. 7} & & 15.2 & & 15 & & 17 & & 17 & & 15 & & 18 & & 18 \\
\hline & u. & & $.9 \mathrm{u}$. & & $.4 \mathrm{u}$ & & $.4 \mathrm{u}$. & & $.9 \mathrm{u}$. & & $.2 \mathrm{u}$. & & $.0 \mathrm{u}$. & \\
\hline \multirow[t]{2}{*}{ Rabbit no. 9} & & 15.2 & & 12 & & 16 & & 16 & & 17 & & 17 & & 16 \\
\hline & $\mathrm{u}$. & & $.9 \mathrm{u}$. & & $.3 \mathrm{u}$. & & $.2 \mathrm{u}$. & & $.4 \mathrm{u}$. & & $\mathrm{u}$. & & $.8 \mathrm{u}$. & \\
\hline \multirow[t]{4}{*}{ Rabbit no. 11} & & 19.6 & & 17 & & 18 & & 21 & & 19 & & 18 & & 18 \\
\hline & $\mathrm{u}$. & & $.4 \mathrm{u}$. & & $.2 \mathrm{u}$. & & $.4 \mathrm{u}$. & & $.1 \mathrm{u}$. & & $.2 \mathrm{u}$. & & $.3 \mathrm{u}$. & \\
\hline & & 16.6 & & 15 & & 17 & & 18 & & 17 & & 17 & & 17 \\
\hline & u. & & $.4 \mathrm{u}$ & & $.3 \mathrm{u}$ & & $.3 \mathrm{u}$. & & $.4 \mathrm{u}$. & & $.8 \mathrm{u}$. & & $.7 \mathrm{u}$. & \\
\hline
\end{tabular}

\begin{tabular}{|c|c|c|c|c|c|c|c|c|}
\hline \multirow[t]{2}{*}{ Animal } & \multicolumn{8}{|c|}{ Burnt group - treated with hyperbaric oxygenation } \\
\hline & $\begin{array}{l}\text { Prior } \\
\text { burning }\end{array}$ & to & $\begin{array}{l}12 \text { hours } \\
\text { after } \\
\text { burning }\end{array}$ & $\begin{array}{l}24 \text { hours } \\
\text { after } \\
\text { burning }\end{array}$ & $\begin{array}{l}2 \text { days after } \\
\text { burning }\end{array}$ & $\begin{array}{l}3 \text { days after } \\
\text { burning }\end{array}$ & $\begin{array}{l}4 \text { days after } \\
\text { burning }\end{array}$ & $\begin{array}{l}6 \text { days after } \\
\text { burning }\end{array}$ \\
\hline 1 & & 2 & 3 & 4 & 5 & 6 & 7 & 8 \\
\hline \multirow[t]{4}{*}{ Rabbit no. 1} & & $0-$ & 0 & 0 & 0 & 0 & 0 & 0 \\
\hline & $1: 50$ & & $-1: 50$ & $-1: 100$ & $-1: 100$ & $-1: 500$ & $-1: 200$ & $-1: 200$ \\
\hline & & $\mathrm{H}-$ & $\mathrm{H}$ & $\mathrm{H}$ & $\mathrm{H}$ & $\mathrm{H}$ & $\mathrm{H}$ & $\mathrm{H}$ \\
\hline & $1: 50$ & & $-1: 50$ & $-1: 100$ & $-1: 100$ & $-1: 500$ & $-1: 400$ & $-1: 400$ \\
\hline \multirow[t]{4}{*}{ Rabbit no. 4} & & 0 & 0 & 0 & 0 & 0 & 0 & 0 \\
\hline & $-1: 800$ & & $-1: 50$ & $-1: 100$ & $-1: 100$ & $-1: 100$ & $-1: 100$ & $-1: 200$ \\
\hline & & $\mathrm{H}$ & $\mathrm{H}$ & $\mathrm{H}$ & $\mathrm{H}$ & $\mathrm{H}$ & $\mathrm{H}$ & $\mathrm{H}$ \\
\hline & $-1: 6400$ & & $-1: 3200$ & $-1: 3200$ & $-1: 3200$ & $-1: 1600$ & $-1: 1600$ & $-1: 3200$ \\
\hline \multirow[t]{4}{*}{ Rabbit no. 5} & & 0 & 0 - & $0-$ & 0 & $0-$ & $0-$ & 0 \\
\hline & $-1: 400$ & & $1: 50$ & $1: 50$ & $-1: 100$ & $1: 50$ & $1: 100$ & $-1: 200$ \\
\hline & & $\mathrm{H}$ & $\mathrm{H}$ & $\mathrm{H}$ & $\mathrm{H}$ & $\mathrm{H}$ & $\mathrm{H}$ & $\mathrm{H}$ \\
\hline & $-1: 3200$ & & $-1: 3200$ & $-1: 1600$ & $-1: 1600$ & $-1: 1600$ & $-1: 3200$ & $-1: 3200$ \\
\hline \multirow[t]{5}{*}{ Rabbit no. 6} & & 0 & 0 & 0 & 0 & 0 & 0 & 0 \\
\hline & $-1: 200$ & & $-1: 100$ & $-1: 100$ & $-1: 100$ & $-1: 50$ & $-1: 100$ & $-1: 100$ \\
\hline & & $\mathrm{H}$ & $\mathrm{H}$ & $\mathrm{H}$ & $\mathrm{H}$ & $\mathrm{H}$ & $\mathrm{H}$ & $\mathrm{H}$ \\
\hline & $-1: 3200$ & & $-1: 3200$ & $-1: 1600$ & $-1: 1600$ & $-1: 1600$ & $-1: 1600$ & $-1: 1600$ \\
\hline & & Con & rol group - bu & & & & & \\
\hline \multirow[t]{4}{*}{ Rabbit no. 7} & & 0 & 0 & 0 & 0 & 0 & 0 & 0 \\
\hline & $-1: 100$ & & $-1: 50$ & $-1: 100$ & $-1: 50$ & $-1: 100$ & $-1: 200$ & $-1: 200$ \\
\hline & & $\mathrm{H}$ & $\mathrm{H}$ & $\mathrm{H}$ & $\mathrm{H}$ & $\mathrm{H}$ & $\mathrm{H}$ & $\mathrm{H}$ \\
\hline & $-1: 3200$ & & $-1: 3200$ & $-1: 1600$ & $-1: 1600$ & $-1: 1600$ & $-1: 3200$ & $-1: 3200$ \\
\hline \multirow[t]{4}{*}{ Rabbit no. 9} & & 0 & 0 & 0 & 0 & 0 & 0 & 0 \\
\hline & $-1: 400$ & & $-1: 100$ & $-1: 100$ & $-1: 50$ & $-1: 400$ & $-1: 100$ & $-1: 100$ \\
\hline & & $\mathrm{H}$ & $\mathrm{H}$ & $\mathrm{H}$ & $\mathrm{H}$ & $\mathrm{H}$ & $\mathrm{H}$ & $\mathrm{H}$ \\
\hline & $-1: 3200$ & & $-1: 3200$ & $-1: 3200$ & $-1: 1600$ & $-1: 3200$ & $-1: 1600$ & $-1: 1600$ \\
\hline Rabbit no. & & 0 & 0 & 0 & 0 & 0 & 0 & 0 \\
\hline \multirow[t]{3}{*}{11} & $-1: 50$ & & $-1: 100$ & $-1: 100$ & $-1: 100$ & $-1: 100$ & $-1: 100$ & $-1: 100$ \\
\hline & & $\mathrm{H}$ & $\mathrm{H}$ & $\mathrm{H}$ & $\mathrm{H}$ & $\mathrm{H}$ & $\mathrm{H}$ & $\mathrm{H}$ \\
\hline & $-1: 3200$ & & $-1: 3200$ & $-1: 3200$ & $-1: 3200$ & $-1: 3200$ & $-1: 3200$ & $-1: 3200$ \\
\hline
\end{tabular}


To complement the above summary it is necessary to add that in 5 tested animals 2 from the group treated with hyperbaric oxygenation and 3 from the control group) the examination carried out after 24 hours and after 6 days showed an increase in the quantities of IgG immunologlobulins whereas in one rabbit from the group subjected to hyperbaric oxygenation, the level of immunoglobulins IgG remained unchanged, and in another rabbit in the same group, after an initial drop in the period of 24 hours, after 6 days there was an observed increase in their concentration.

In all animals the titer in ASTA reaction was maintained within 0.5 to $2 \mathrm{u}$. in the entire observation period whereas in one animal (rabbit no. 4) treated with hyperbaric oxygenation - the titer in the 6th day of the observation increased to $4 \mathrm{u}$. of anti-staphylolysins.

The examined animals showed good tolerance of the thermal injury, revealed no complications in the form of secondary infection developing in the wound.

The thermal injury covered with a scab that gradually separated from the wound in the course of the healing process.

From the conducted histopathological tests, it stems that the necrosis resulting from the napalm burn affected the epidermis, the dermis with appendages, the dermal muscle and subcutaneous tissue, however, the largest necrotic lesions were noted in the epidermis and the superficial layer of the skin. In rabbits examined immediately following the burn, separation of the superficial layers of the epidermis was noted, resembling intraepidermal and subepidermal blistering. In multiple locations, cellular nuclei of the epidermis were significantly extended, similarly to those observed in epidermal necrosis induced by electric shock.

Rabbits examined 8 days after burning indicated a lack of epidermal cover, a considerable pressure of neutrophils at the borderline of necrotic lesions and deep tissues, which resembles the demarcation process.

A characteristic feature involved focal inflammatory infiltrations in the deep layers of the dermis and muscles. On the $40^{\text {th }}$ day following burning an advanced healing of the burn wound was noted under the scab.

Its surface was formed by granulation, and the wound was covered with migrating epidermis from the peripheral area. In the place of the granulation, a low vascularised connective tissue was formed, rich in thick collagen fibres, with sparse fragments of elastic and smooth muscle fibres noted in some places.

In other locations, scant inflammatory infiltrations were seen in this period, mainly formed from mononuclear cells. In the subdermal muscle, on the other hand, focal or spread fibrosis was noted, whereas in the deep layers of the dermis and in subcutaneous tissue numerous thick-walled arterial and venous vessels with broad lumen.

In the comparison of microscopic images of the skin of burnt animals treated with hyperbaric oxygenation and the control group it seemed that in animals subjected to hyperbaric oxygenation the processes of separation of the scab, removal of necrotic tissues, granulation and occurrence of connective scar tissue were more advanced.

\section{DISCUSSION AND CONCLUSIONS}

The presented material is not sufficient to draw binding conclusions, however it may serve as a reference point for further research.

not subjected to this treatment, changes in the complement activity in the blood serum, consisting in its increase, were noted., similar to what was observed in the previous studies $[9,10]$, however this time the said rise was commonly preceded with a decreased activity (error of the method 10\%).

It should be added that in untreated animals such an increase was more rapid and occurred already after 24 hours, whereas in those treated it occurred as late as 3 days afterwards.

As far as haemagglutination reaction is concerned, no clearly directed transitions were observed, however, in both groups a general increase in IgG immunoglobulins was noted. The results of ASTA reaction did not signal any complications in the form of staphylococcus infection in the tested animals [4].

The obtained results regarding shifts in the titer of the activity of the complement and IgG immunoglobulins may be explained in accordance with Selye's theory concerned with the response of an animal organism to a thermal injury and hyperbaric oxygenation, which in the first stage of an alarm reaction results in the stimulation of the sympathetic system.

This entails an increase in the quantities of sympathetic immunological bodies (e.g. complement, opsonines) with a simultaneous decrease in parasympathetic ones (agglutinins, haemagglutinins).

Similar observations have been made before in animals subjected to hyperbaric oxygenation $[1,9,10$, 11]. On the basis of the examined material it is not possible to explain the drop in the complement activity in burnt animals treated with hyperbaric oxygenation as the said decrease in burnt rabbits (both treated and not treated with hyperbaric oxygen) seems to be the organism's reaction to a thermal injury.

The same applies to IgG immunoglobulins in both tested groups of animals, whose increase in later periods seems characteristic of a thermal injury.

The results of histopathological tests confirm a significant thermal damage in the tested animals, with the characteristic feature consisting in the fact that the healing process was more prominent in animals treated with hyperbaric oxygen, as confirmed with data from the available literature $[7,8]$.

Nonetheless, the above studies require further confirmation on a larger material sample and with consideration of other serological tests. 


\section{BIBLIOGRAPHY}

Doboszyński T., Ulewicz K., Łokucijewski B., Michniewski P.,: Ann.Immunol. 1970.4;245.

Dolatkowski A., Ulewicz K., (ed.): The outline of physiopathology of diving. PZWL. Warsaw 1973.

Harter F.: Arzl.Mitt. 1962.47/59;2503.

Ingestad R., Winblad A.: Acta path.microb.scand. 1963.57;455.

Moretti G., Fontanesi S., Chittoni L.: Annali di Med. Navale. 1973.48.1;11.

Niedworok J.: Experimental studies on the immunological phenomena in napalm-induced burn disease. Łódź 1973.

Proceedings of the Fourth International Congress on of Hyperbaric Medicine. Ed.Brown j.Jr., Cox B.Washington 1966.

Proceedings of the Fourth International Conference on Hyperbaric Medicine. Ed.Wada J., Iwa T. Tokyo. 1970.

Ulewicz K.: Ann.Immunol.Hung. 1971.15;121.

Ulewicz K., Michniewski P.: Ann.Immunol.Hung. 1971.15;129.

Ulewicz K., Michniewski P., Łokucijewski B., Doboszyński T.: Przegl.Lek. 1971.9;581.

Zanini D., Bogetti B., Arkel F.: Lav.e Med. 1966.20;4;175

Zenini D., Bogetti B., Viotti G.: Lav.e Med. 1967.21.5;177.

\section{Kazimierz Ulewicz}

Katedra Medycyny Morskiej Wojskowej Akademii Medycznej,

Gdynia 